\title{
Business Ethics-Does it Pay
}

\section{RESEARCH ARTICLE}

\section{Kumar Umesh}

\author{
UshmaUrja Apartments, Sec-62, Noida (U.P.), India.
}

Corresponding Author: E-mail:umeshdhanwal@gmail.com

\begin{abstract}
This study investigates the UK and US companies who had codes of ethics/conduct/Principles and those who explicitly said they did not. This study relies on the data which was available from various secondary sources like Annual report of companies, Ratings given by different agencies to name a few. We divided companies into two cohorts - who had code of ethics and without it. We have done an extensive research and filtered companies from the list of 581 companies. We then tried to find relationship between financial and non financial parameters. We have tried to relate both and show its effect on the companies. The above figure clearly shows that the companies who are better able to manage its stakeholders i.e. Customers, employees and investors are better able to increase the financial impact in the form of increase of lower costs, premium price products etc. to name a few. The findings that we have got are also testimony to this fact. On the other hand, we have looked onto the financial performance in the form of EVA, MVA, ROCE and P/E ratio volatility. The results we have got clearly favours the companies which have a code of ethics in the form of higher MVA, EVA, ROCE and lesser P/E volatility as compared to others which doesn't have it. Thus, it is important for companies to better able to manage its code of ethics in place in order to have greater growth on all aspects.
\end{abstract}

Keywords:Businessethics, Companies, EVA,MVA.

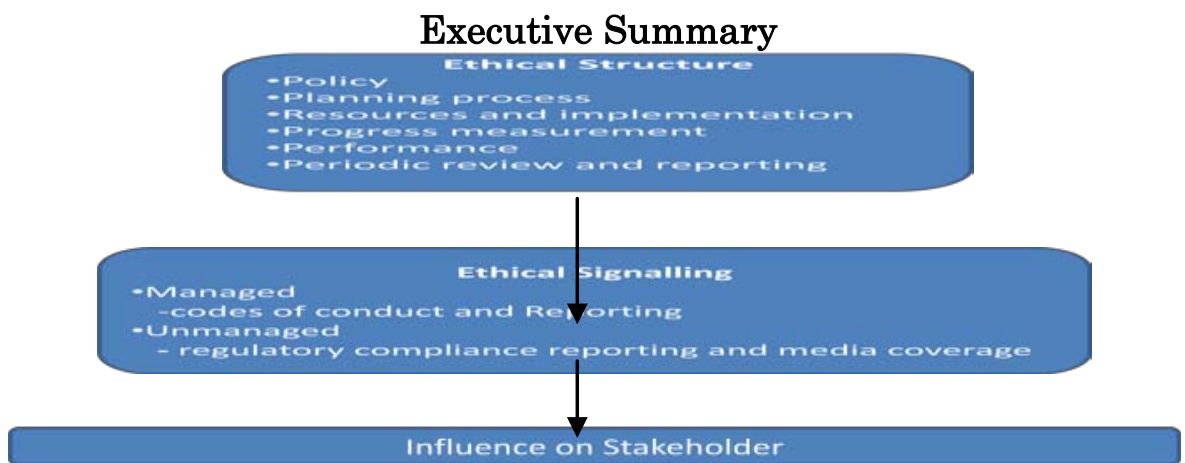

Influence on Stakeholder
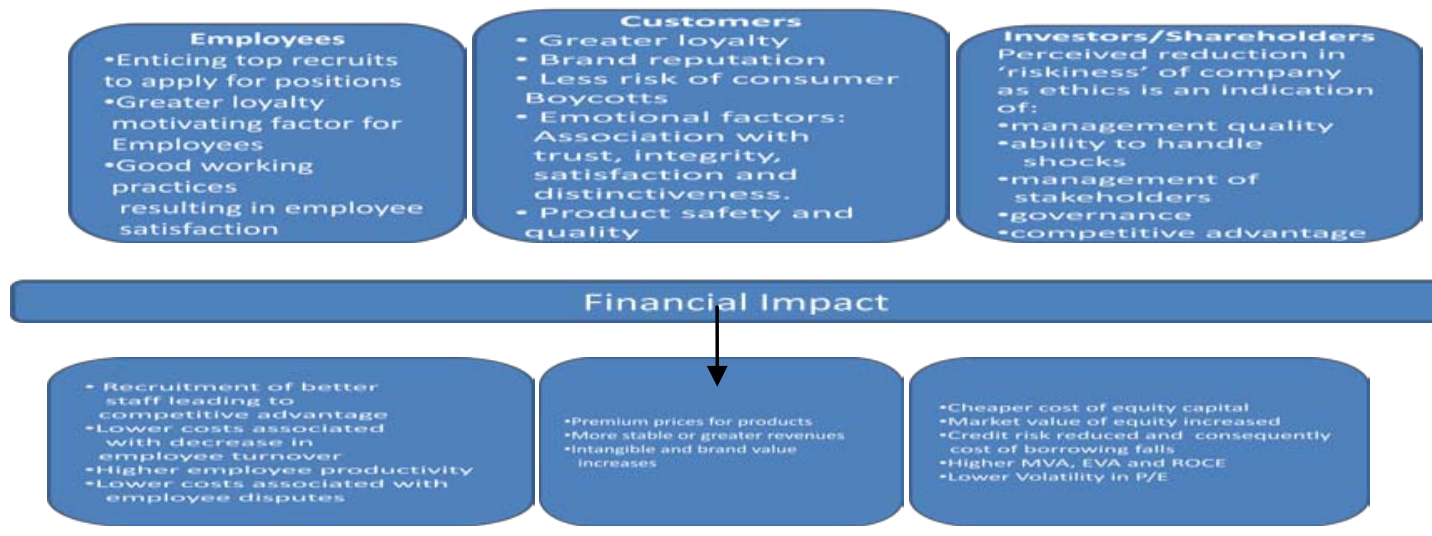


\section{Introduction}

There is an integral strategy of a firm which leads to an improvement in the competitiveness of a firm, if it is following a business approach that respects ethics, people, communities and the environment is called Corporate Social Responsibility (CSR). In the last few decades, the companies were able to realise the business benefits of following CSR policies and practices. There is a growing pressure not only from customers or suppliers but also other stakeholders i.e. employees, communities, investors, activist organisations in order to increase their efforts towards expanding CSR. As companies have got an increasing global market presence there is a greater obligation on them in order to divulge information to the public.The increasing demand from various sections of the society led to a sharp increase in the number of CSRrelated instruments. These instruments can be categorised in three categories:

- Codes of conduct

- Management standards

- Accounting/reporting standards

The feel good factor and CSR has led many large organisations to not only focus on financial performance but also on environmental and social performance. Triple bottom is reporting is the terminology often seen in the company's annual reports. This concern has led them to ponder about how reputation affects shareholder's perception. There are some very good commercial justifications for companies in order to structure their activities so that they become more attractive to various investors. There is growing circulation of information by corporate about their activities. There are large numbersof companies which issue annual reports about their year's activities coupled with the financial status. Some of the companies responded to the need of information relating to the social performance by developing some sort of corporate social reporting.There are various research conducted on how reputation lead to benefits in terms of increased sales, customer loyalty etc. There were research conducted on specific indicators of CSR like environmental management, sustainability etc. on firm's bottomline. They had positive but not definitive relationship between the two variables. This study would provide conclusive evidence by studying across 581 companies.

\section{Methodology Used in Research}

I have limited out research to companies in UK and US as their headquarters because almost $80 \%$ of the companies in the list are from these countries. The list of most ethical companies is collected from Covalence $^{1}$ by picking up US and UK companies out 581 companies ranking.I have filtered companies that are consistently present from 2006 till 2010 and have code of ethics/conduct/principles for five years.The areas of research was extended beyond used in the original study by Webley(2003) and I have included new areas which were unexplored i.e. employee turnover, cost of capital and customer retention. There was a divide of companies that have codes (56) and companies with no codes (39). The following chart was prepared which helps in identifying the areas of our research.

\section{Non-Financial Performance}

Berman and Wicks paper Does Stakeholder orientation matter? The relationship between stakeholder management models and firm financial performance' worked on US data, union relations, employee involvement in decision making, cash profit sharing and fines received which were proxies for employees. The other proxies were product safety and quality in lieu of customers.In case of US companies we have used $\mathrm{KLD}^{2}$ database for ratings and in case of customers the methodology would be discussed. The ratings were primarily used for policies, processes and performance of companies human resources management. The KLD database consists of 650 USfirms on the parameters already discussed. Thus, using similar methodology we have used the following other proxies for UK and US.

\section{Employees}




\begin{tabular}{|c|c|c|c|}
\hline \multicolumn{4}{|c|}{ Areas of interest } \\
\hline Financial performance & Data considered & $\begin{array}{l}\text { Non- } \\
\text { financial } \\
\text { performance }\end{array}$ & Data considered \\
\hline Market value added (MVA) & Annual report and yahoo finance & Employees & $\begin{array}{lr}\text { Labour } & \text { turnover } \\
\text { statistics, } & \text { Core } \\
\text { ratings } & \text { risk } \\
\text { assessment, } & \text { SERM } \\
\text { employeer risk } \\
\text { ratings, } \\
\text { relations, Employee } \\
\text { involvement in } \\
\text { decision-making, } \\
\text { Cash profit sharing } \\
\text { and fines received } \\
\text { Britain's and USA's }\end{array}$ \\
\hline Economic value added (EVA) & Annual Report and Yahoo Finance & $\begin{array}{l}\text { Customer } \\
\text { and } \\
\text { reputation }\end{array}$ & $\begin{array}{lr}\text { Most } & \text { admired } \\
\text { companies, } & \text { MORI } \\
\text { reputation } & \\
\text { information } & \end{array}$ \\
\hline Price to earnings ratio (P/E Ratio) & Johnson, H. - Research paper & $\begin{array}{l}\text { Origin of top } \\
\text { management }\end{array}$ & $\begin{array}{lr}\text { CEO } & \text { origin } \\
\text { information } & \text { in } \\
\text { company reports }\end{array}$ \\
\hline $\begin{array}{l}\text { Return on capital employed } \\
(\mathrm{ROCF})\end{array}$ & Annual Report & & \\
\hline Cost of capital & $\begin{array}{l}\text { S\&P Ratings, Pricing differentials } \\
\text { - Barclays bank, loan and interest } \\
\text { payment Information - company } \\
\text { annual reports }\end{array}$ & & \\
\hline
\end{tabular}

The proxies that were considered are labourturnover, employment tribunal information and ratings agency data.

\section{Labour Turnover data}

I have gathered the following costs are associated with labour turnover:

- Leaving Costs-payroll and personnel administration of leaver

- Replacement Costs - recruitment, interview time, placement fees

- Transition Costs-training costs, unproductive' time whilst learning, induction

- Indirect Costs - loss in customer service/ satisfaction

These costs will have a direct impact on profitability. I have used secondary database which is Chartered Institute of Personnel and Development (CIPD)

\section{Labour Turnover Surveys}

Labour Turnover $=$ Number of leavers in a set period $\times 100$ Average no. employed in that period
(Leavers include those going from the organisation by way of voluntaryor involuntary severance, redundancies and retirements, but do not include internal transfers.)The CIPD data is also broken into occupational group, industry and organisation size. [1-5] The above data can be used for getting the costs of the companies which were part of our research. The data would help us in calculating the direct cost to each company for each period of a vacancy.

\section{Employment Tribunal Application Analysis}

The employment tribunal applications were collected for the five year period i.e. 2006-2010.

\section{Rating Agency Data}

Policies, processes and performance of a company's human resources management is done by a number of rating agencies. They 
Table 2: Average labour UK and US turnover : 2006-2010

\begin{tabular}{llllll}
\hline Type of employee & $\mathbf{2 0 0 6}$ & $\mathbf{2 0 0 7}$ & $\mathbf{2 0 0 8}$ & $\mathbf{2 0 0 9}$ & $\mathbf{2 0 1 0}$ \\
\hline Full time & 16.64 & 17.64 & 16.3 & 20.9 & 23 \\
Part time & 29.15 & 29.15 & 21.5 & 29.6 & 27.1 \\
All employees & 19.82 & 19.82 & 18.3 & 26.6 & 27.8 \\
\hline
\end{tabular}

Table3: Average number of weeks taken to fill a vacancy

\begin{tabular}{lccccc}
\hline \multicolumn{1}{c}{ Occupational group } & $\mathbf{2 0 0 6}$ & $\mathbf{2 0 0 7}$ & $\mathbf{2 0 0 8}$ & $\mathbf{2 0 0 9}$ & $\mathbf{2 0 1 0}$ \\
\hline Managers / administrative & 12.15 & 12.91 & 12.1 & 13.5 & 14.1 \\
Professional & 13.25 & 14.05 & 13.8 & 13.9 & 13.8 \\
Assoc. Prof., technical and scientific & 12.31 & 12.83 & 11.9 & 13 & 14.1 \\
Clerical and Secretarial & 6.53 & 6.78 & 6.7 & 6.8 & 6.9 \\
Sales & 9.17 & 10.32 & 9.7 & 10.6 & 10.7 \\
Personal service & 6.81 & 7.73 & 6.9 & 7.3 & 7.9 \\
Craft and skilled manual & 7.11 & 7.85 & 7.5 & 7.5 & 7.6 \\
Operative and assembly manual & 4.67 & 4.55 & 4.5 & 4.7 & 4.8 \\
Routine unskilled manual & 4.61 & 4.9 & 4.7 & 4.9 & 5.1 \\
Other & 7.71 & 8.11 & 7.3 & 8.3 & 8.7 \\
Average & 9.10 & 9.2 & 10.5 & 11.1 & 12.1 \\
\hline
\end{tabular}

tend to use the publicly available data and do qualitative analysis on it. The databaseselected for our research is SERM $^{3}$ ratings and $\mathrm{KLD}$.

\section{Customer}

UK's most admired and USA's most admired companies list was used.Customer retention forms an important part of strategy of a company. We have tried to identify the proxies for it and came out with the UK's most admired and USA's most admired companies. UK's corporate reputation resultswere compiled from the survey work of Michael Brown of Nottingham University and in the case of USA's the corporate reputation results of New York University's Reputation Institute were used.

\section{Cost of Capital}

Bond prices, credit ratings and beta values were the three measures identified. Beta values were not used as they reflect an outcome of a company's cost of capital rather than a determinant. On the other hand, bondprices reflect the past financial performance, underlying assets, expected cash flows and

Table4: Pricing based on spread to Gilts

\begin{tabular}{lc}
\hline \multicolumn{1}{c}{ Rating } & Pricing (\%) \\
\hline AAA & 0.45 \\
AAA- $^{-}$ & 0.55 \\
AA & 0.65 \\
AA & 0.75 \\
AA & -0.9 \\
A+ & 1.05 \\
A & 1.22 \\
$A^{-}$ & 1.39 \\
BBB+ & 1.56 \\
BBB & 1.73 \\
\hline
\end{tabular}

Profitability, volatility of firms' assets, existing debt levels, maturity of debt etc. We have to control these factors and perform further indepth analysis. Thus, we were left with only one choice and it was better as it focuses on the company rather than looking at a specific event. The ratings tend to look on the likelihood of an event of default rather than the upside potential. We have used S\&P as proxy for the cost of capital. We have obtained the average interest rates from Barclays bank for the credit grades and used it for showing the difference in cost of borrowing between the companies[6]. 


\section{Corporate Top Management}

We have looked onto the data of the CEO appointed from various newspapers like Financial Times, New York times in order to found whether the CEO appointed within the organisation has spent five years or more within an organisation prior to being appointed as $\underline{C E O}$ within the company. This list was made for both companies without codes or with codes in order to establish the relationship. After gathering the above data, we have used the following hypothesis

- Companies with a code of ethics would generate significantly more economic value added (EVA), market added value (MVA), lower volatility in Price to Earnings (P/E) ratio, high Return on Capital employed (ROCE) than those without codes.

- Companies with a code of ethics would generate significantly less employee turnover, higher ratings, greater customer retention, lower cost of capital and more CEO appointed from within the organisation (spent 5 years or more in an organisation).

\section{Result and Interpretation}

\section{Financial Performance and CSR}

We have statiscally analysed tried to analyse the correlation between the two cohorts that is with codes and without codes with EVA, MVA, ROCE (given by Table 1).Secondly, a dummy variable test has been conducted in order to test for the attribute that the firm which are socially responsible in relation to another attribute which is profitability. We have assigned a dummy variable of 1 to a company which is socially responsible as compared to 0 to the company not having it. Thus, we were able to analyse whether having code of ethics is positive, negative or no impact on profitability as measured by EVA, MVA, ROCE (given by Table 2). The measures i.e. ROCE,MVA, and EVA and its relationship with CSR is indicated by the strength and sign of relationship. The results are considered to be significant in case the value of $\mathrm{P}$ is at the 5 percent significance level or less. The adjusted R-square gives an indication of the independent variables (here it is CSR) helps us in explaining all of the variations in the above three variables. A value of 0 gives an indication of very little of the variation being explained by the independent variables.The above results clearly gives an indication of significant and positive relationship between being one of the companies having code of conduct (56 companies) and EVA,MVA and ROCE. Thus, there is significant and positive correlation between the CSR and three variables.It can thus be interpreted that having an improvement in the bottom line is dependent on whether there is existence of code of ethics or not along with the perception of the investors and other stakeholders about the company.

\section{Cost of Capital}

We have seen across the data and found a difference of $0.51 \%$ in between the companies which have a code as compared to those without it. This can be seen in the form that in case a company has got an embedded ethics policy and borrow an amount of 1,000,000. They would be able to save 5100 as compared to those that do not have an overt ethics policy. We have also looked onto the companies report and found that the actual interest rate difference between the two cohorts during the period was $2.1 \%$. For e.g.The average borrowing for the companies was $\$ 1,976,000,000$.This translates into an average difference in interest costs of $\$ 41,000,000$.We were not able to show the volatility of P/E ratio in comparison to the company having code of ethics as compared to those who do not have it due to constraint of words. However, we have relied on the Johnson H. (2003) in order to conclude that companies having code of ethics leads to less volatility as compared to those who have it.

\section{Non -Financial Performance and CSR}

In the below sections we would be looking at the various non financial costs one by one:

\section{Employers}

\section{Labour Turnover Costa}

Hypothesis:The companies with a code of ethics would be having lower turnover costs which directly affects profitability.The above 
Available online at www.managementjournal.info

Table 5: analyse the correlation between the two cohorts that is with codes and without codes

\begin{tabular}{lllllll}
\hline \multirow{3}{*}{ Correlation results } & & 2006 & 2007 & 2008 & 2009 & 2010 \\
\cline { 2 - 7 } & Correlation with EVA & 0.687 & 0.767 & 0.754 & 0.665 & 0.876 \\
& Correlation with MVA & 0.876 & 0.656 & 0.565 & 0.875 & 0.763 \\
& Correlation with ROCE & 0.565 & 0.767 & 0.876 & 0.656 & 0.676 \\
\hline
\end{tabular}

Table 6: Negative or no impact on profitability as measured by EVA, MVA, ROCE

\begin{tabular}{lcccc} 
& Dependent variable & Adj. R-Sq & Beta coeff. & P-value \\
\cline { 2 - 5 } Regression analysis results: & EVA06 & 0.032 & 0.07 & 0.111 \\
dependent variable as a function & EVA07 & 0.024 & 0.05 & 0.146 \\
of CSR & EVA08 & 0.034 & 0.16 & 0.147 \\
& EVA09 & 0.045 & 0.15 & 0.145 \\
& EVA10 & 0.035 & 0.19 & 0.133 \\
& MVA06 & 0.045 & 0.13 & 0.127 \\
MVA07 & 0.054 & 0.12 & 0.134 \\
MVA08 & 0.067 & 0.13 & 0.142 \\
& MVA09 & 0.045 & 0.09 & 0.113 \\
& MVA10 & 0.054 & 0.17 & 0.118 \\
& ROCE06 & 0.087 & 0.12 & 0.134 \\
ROCE07 & 0.034 & 0.11 & 0.111 \\
ROCE08 & 0.035 & 0.12 & 0.226 \\
ROCE09 & 0.045 & 0.19 & 0.114 \\
\hline
\end{tabular}

Table7:Estimated Labour Turnover Costs (\$ per person)

\begin{tabular}{|c|c|c|c|c|c|}
\hline Occupational group & 2006 & 2007 & 2008 & 2009 & 2010 \\
\hline Managers / administratives & 4560 & 4939 & 4762 & 6086 & 7067 \\
\hline Professional & 4669 & 4621 & 5206 & 5813 & 6743 \\
\hline Assoc. Prof., technical and scientific & 3598 & 3623 & 3999 & 4591 & 5345 \\
\hline Clerical and Secretarial & 1681 & 1733 & 1906 & 2215 & 2653 \\
\hline Sales & 3316 & 4669 & 3917 & 4179 & 5320 \\
\hline Personal service & 1894 & 1491 & 1961 & 1589 & 1786 \\
\hline Craft and skilled manual & 1377 & 1526 & 1648 & 1736 & 1953 \\
\hline Operative and assembly manual & 947 & 1158 & 1350 & 1225 & 1453 \\
\hline Routine unskilled manual & 773 & 845 & 1127 & 895 & 1423 \\
\hline Other & 1881 & 1385 & 1839 & 1779 & 1987 \\
\hline Average & 2876 & 3100 & 3546 & 3933 & 4300 \\
\hline Average of Companies (with ethics) & 2675 & 2900 & 3233 & 3656 & 3987 \\
\hline Average of Companies (without ethics) & 3077 & 3300 & 3859 & 4210 & 4613 \\
\hline
\end{tabular}


Table 8: The companies with code of ethics

\begin{tabular}{lcc} 
Years & $\begin{array}{c}\text { Applications as } \% \text { of } \\
\text { no. employees }\end{array}$ & $\begin{array}{c}\text { with no } \\
\text { applications }\end{array}$ \\
\hline 2006 & $0.10 \% *$ & $33 \%$ \\
2007 & $0.04 \%$ & $59 \%$ \\
2008 & $0.09 \% *$ & $25 \%$ \\
& $0.05 \%$ & $65 \%$ \\
2009 & $0.16 \% *$ & $25 \%$ \\
& $0.06 \%$ & $71 \%$ \\
2010 & $0.19 \% *$ & $15 \%$ \\
& $0.07 \%$ & $47 \%$ \\
& $0.23 \% *$ & $13 \%$ \\
\end{tabular}

Table 9: SERM and KLD average risk avoidance rating

$\begin{aligned} & \text { With code of } \\ & \text { ethics }\end{aligned}$
ethics

Average 3.1

*higher ratings means greater risk avoidance

\section{Employment Tribunal Application Analysis}

Hypothesis: The companies with a code of ethics would be having higher applications made to employment tribunal as compared to companies without code. The above data clearly supports our hypothesis that companies with the code of ethics are better off as compared to the companies without code of ethics in terms of applications to tribunal. Another insight from the above data is that there is an increase in the proportion of applications made to employment tribunal in the case of companies with code of ethics as compared to companies without it. The companies with code of ethics has got good working practices, employee satisfaction and lower costs associated with employee disputes as evident from the proxy of above data.

\section{Rating Agency Data}

Hypothesis: The companies with a code of ethics would be having higher risk avoidance rating as compared to companies without code. The above table clearly supports our hypothesis that companies with a code of ethics

are having a better risk avoidance rating as compared to companies without it. This shows that companies with code are having better
Table 10:Most admired companies in UK and USA

\begin{tabular}{lcc}
\hline \multirow{2}{*}{$\begin{array}{l}\text { Year } \\
\text { s }\end{array}$} & \multicolumn{2}{c}{ As \% of total number of companies } \\
\cline { 2 - 3 } & $\begin{array}{c}\text { With code of } \\
\text { ethics }\end{array}$ & $\begin{array}{c}\text { Without code of } \\
\text { ethics }\end{array}$ \\
\hline 2006 & $72 \%$ & $29 \%$ \\
2007 & $72 \%$ & $35 \%$ \\
2008 & $75 \%$ & $65 \%$ \\
2009 & $76 \%$ & $32 \%$ \\
2010 & $78 \%$ & $27 \%$ \\
\hline
\end{tabular}

Table 11: CEO's appointed from within the organisation

\begin{tabular}{ll} 
With Code of ethics & Without Code of ethics \\
$53 \%(9$ out of 17$)$ & $70 \%(16$ out of 23$)$ \\
\hline
\end{tabular}

stakeholder relation as compared to companies without it.

\section{Customers}

Hypothesis: Companies with code of ethics would be more in the list of the most admired companies as compared to companies without code.The companies with code of ethics clearly support our hypothesis and rank consistently among the most admired companies as compared to companies without code of ethics. This shows that companies are perceived by others as having good working practices as compared to companies without having code of ethics. Thus, there is an expectation from us that companies which are perceived as having better reputation would be having a greater impact on buying decision of customers and subsequently increase bottom-line of companies.

\section{Corporate Top Management}

Hypothesis:Companies with code of ethics would be having more employees being raised to the level of CEO from within (having spent 5years as compared to companies without code. CEO appointed from within the organisation. The above table clearly supports our hypothesis about the CEO's which are appointed from within the organisation. This shows that employees spent more time with companies having code of ethics and acquire top position in that organisation [1-8]. 


\section{Conclusion and Remarks}

The above results clearly lay out the clearpathin terms of benefits which an ethical company enjoys as compared to an unethical company. We have started out with the effect that companies have on various stakeholders involved in the business. We knew that there are certain effects that employees would have on the costs of the company, customer's preference towards the product of the company, and shareholders / investors on the $\mathrm{P} / \mathrm{E}$ volatility. The companies who do not have

\section{References}

1. Covalence Ratings (2003) http://www.ethicalquote.com/index.php/ethicalrankings/, website accessed on 8 Nov. 2011.

2. Simon Webley Risk, reputation and trust, J. Communication Management, 8 I(1):9 - 12 .

3. Chartered Institute of Personnel and Development Database, website accessed on 11 Nov. 2011

4. Search Engine Reputation Management (SERM) database, website accessed on 11 Nov. 2011.

5. S\&P ratings, website: www.standardandpoors.com/ratings, accessed on 8 Nov 2011. disclosure must now pay heed to the fact that CSR leads to an increase in the bottom-line of the company along with the greater good to society. The companies need to have greater disclosure of CSR activities in their annual report so that information is properly disseminated to the public. There are some of the observations where we seen that there are clear changes and marked difference between ethical companies as compared to other companies. Thus, the question that alludes us all that does it pays? Is answered by "Yes it pays."

6. Johnson, H. (2003). Does it pay to be good? Social responsibility and financial performance. Business Horizons 46(6): 34-40.

7. Reputation Institute website (http://www.reputationinstitute.com/) Stern School ofBusiness, New York University.

8. Shawn L Berman, Andrew C Wicks, Suresh Kotha, Thomas M Jones (1999) Does stakeholder orientation matter? The relationship between stakeholder management models and firm financial performance. The Academy of Management Journal42(5):488-506 